\title{
ВЛАСНІ НАЗВИ У ФАНТАСТИЧНІЙ ПОВІСТІ ВОЛОДИМИРА ВЛАДКА «ФІОЛЕТОВА ЗАГИБЕЛЬ»
}

Кушлак Л. С. Власні назви у фантастичній повісті Володимира Владка «Фіолетова загибель».

У статті висвітлено основні аспекти дослідження власних назв у художніх текстах. Метою цієї розвідки $\epsilon$ аналіз вживаних онімних одиниць у творах українських письменників-фантастів, які досі не були під пильною увагою науковців.

Ключові слова: літературна ономастика, власна назва, антропопоетонім, космопоетонім. гибель».

Кушлак Л. С. Имена собственные в фантастической повести Владимира Владка «Фиолетовая

В статье освещены основные аспекты исследования имен собственных в художественных текстах. Целью данной разведки является исследование применяемых онимных единиц в произведениях украинских писателей-фантастов, которые еще не были под пристальным вниманием ученых.

Ключевые слова: литературная ономастика, имя собственное, антропопоэтоним, космопоэтоним.

Kushlak L. S. Proper names in a fantastic tale of Vladimir Vladko «Purple death».

In the article the basic aspects of research of the proper names in artistic texts are reflected. The purpose of this investigation is research of common onomastic's units in works of Ukrainian writers-fantasies, who were not under intent attention of researchers until now.

Key word: literary onomastics, proper name, anthropopoetonym, kosmopoetonym.

Наукова фантастика - це жанр художньої літератури, метою якого $є$ художнє зображення вигаданого фантастичного світу як реально існуючого на підставі чотирьох ознак: фантастичності, науковості, орієнтації на сучасність і спрямованості у майбутнє. Засновниками науково-фантастичної літератури в Україні можна вважати В. Винниченка та Ю. Смолича. Сучасними представниками цього жанру є О. Авраменко, В. Владко, Н. Гайдамака, Н. Околітенко, Л. Панасенко, І. Росоховатський та інші майстри художнього слова.

Мова сучасної наукової фантастики органічно поєднує в собі як пізнавальну, естетичну, так i iнформаційно-комунікативну функції. Слововживання відомих письменників, які працюють у жанрі сучасної наукової фантастики, свідчить про те, що автори використовують лексику, яка допомагає читачу осягнути зміст твору за допомогою образності мови.

Незважаючи на значну кількість ономастичних досліджень, твори українських письменників-фантастів ономастами не аналізувалися у повному обсязі, що й зумовлює актуальність теми нашої наукової розвідки. Безпосередньо об'єктом дослідження $\epsilon$ власні назви, зафіксовані у фантастичній повісті Володимира Владка «Фіолетова загибель».

Цей твір містить 80 різнопланових онімів, які вживаються 3275 раз. Найбільш часто фіксуються антропопоетоніми (3157, що становить 96,4 \%: від загальної кількості слововживань): Клайд уже зійшов схилом і пірнув у густу тінь кедрів над річкою; Джеймс засоромлено блимнув очима). Епізодично фіксуються хоропоетоніми (49; 1,5 \%): Кінець кінцем, переміг північний захід і його серие - штат Айдахо...; космопоетоніми (30; 0,9 \%): 
Якби ти цікавився наукою, - відповів він, - то знав би, щзо в Сонячній системі, крім звичних для нас планет, як-от: Земля, Марс, Венера, Юпітер та інші, була ще одна - вона колись розсипалась на уламки. Вчені назвали ї̈ Фаетоном; товаропоетоніми (15; 0,46\%): Наприклад, щзось подібне до антибіотика. Космоцилін?.. Астроміцин?.. Астроміцин СТ хіба не ефректно?, фірмопоетоніми $(11 ; 0,34 \%)$ : ...так изе хмарочос ОфрфісСейнтер, щз поєднав волею випадку їхні установи; $А$ може бути, «Індастрі ов Кемікал продактс», - чуе годиться ци для них...; репертіпоетоніми (6; 0,18\%): Om $i$ вийшли три чашки Петрі; едитопоетоніми (2; 0,06 \%): ... Шофер автофургона, якого вони найняли в Бойсі, щзб дістатися до схилів Скелястих гір; архітектуропоетонім (На різні військові справи витрачається купа грошей, для того й існує Пентагон; гемеропоетонім (Це - останні номери «Попюлар сайєнс»); гідропоетонім (Тим більще, щзо вже давно встановлено: у річизі Снайк та ї̈ притоках, схожих на цей струмок, ніяких дорогоиінних металів немає); порейопоетонім (Це $\mathbf{У}-2$ чи які-небудь нові шпигунські літаки Локхіда) i фільмопоетонім (I не просто якесь невідоме місто, а Сан-Франціско, $i$ бачив він цуе в кінофільмі Стенлі Крамера «на далекому березі») - по 1 $(0,03 \%)$. Очевидно, що В. М. Владко багато уваги приділив добору власних назв, оскільки кожна 3 них несе необхідне для фантастичної повісті смислове навантаження, важливе для іiі цілісного розуміння.

Детально розроблена письменником антропонімійна система повісті $\epsilon$ одним 3 найцікавіших компонентів твору. Серед антропопоетонімів найбільш вживаним є прізвище та ім'я головного героя - Maрчі (134 фіксації), Джеймс (667), а також його прізвисько - Коротун (208) i пестливий варіант - Коротунчик (16). Крім того, у творі ми зустрічаємося 3 деякими іншими особовими назвами. Передусім це друзі головного героя Клайд (795) Тальбот (35), Фред (665) Стапльтон (119), дівчина Меджі (452) Бейкер (30), а також іï зменшено-пестливе ім'я - Бебі-долл (5). Ще у повісті присутні імена подруги Меджі - Люсі (7) і Уінклер (1) та інші імена, які не мають особливого значення для онімного простору цього твору.

Варто зазначити, що походження використаних у творі імен різноманітне: тут зафіксовано давньоєврейську, німецьку i латинську власні особові назви, кожна 3 яких несе в собі певне змістове навантаження.

Джееимс (James) - давньоєврейське ім'я, що в перекладі означає «той, що дивиться в майбутнє» [4].

Фред (Fred) - варіант імен Фрідріх, Альфред. Фрідріх означає «який володіє світом»[2, с. 460]; Альфред - «порадник». Чоловіки, які носять це ім'я, зазвичай пристрасні, енергійні натури, схильні до лідерства. Альфред дуже самовпевнений, гордий і незалежний. Він має величезну внутрішню силу, що може допомогти йому домогтися успіхів у кар'єрі. Альфред честолюбний, спілкування з ним буває не завжди легким. Альфред часто 
поводиться зарозуміло, підкреслюючи при цьому свою перевагу над співрозмовником [2, с. 239-240].

Лусі (Лусія, Люсія) - жіноча форма чоловічого імені Лусіус, має латинські корені, означає «сяюча, блискуча» або «народжена на світанку» [2, c. 113].

Особливу увагу привертають до себе антропоніми, не зафіксовані в наукових розвідках. До них у повісті належать імена Меджі та Клайд. Їхнє походження важко пояснити, та слід зазначити, що, виходячи зі змісту досліджуваного твору, ці антропоніми несуть у собі певну ідею. Зокрема, автор використав не банальні, а оригінальні імена для надання повісті особливого відтінку. На нашу думку, ім'я Меджі використано замість загальновживаного i звичного Марія. У наукових розвідках ми не знаходимо історії виникнення таких найменувань, тому можемо робити лише окремі припущення. Так, психологи та езотерики стверджують, що про кожного 3 нас можна дізнатися чимало цікавого лише за першими літерами імені і прізвища. Згідно з такою теорією, розглянемо перші літери антропоформул героїв твору. Отже, отримаємо такі результати:

Джеймс Марчі: Д - комунікабельність, вміння привертати увагу до себе; $M$ - працелюбність і педантичність;

Клайд Тальбот: $K$ - таємничість; $T$ - нескінченні пошуки, гонитва за ідеалом;

Фред Стапльтон: $\Phi$ - вміння пристосовуватися; $C-$ нервовість, пригніченість;

Меджі Бейкер: $M$ - працелюбність і педантичність; $D$ - здатність на велике почуття [3, с. 98-99].

Певну роль у розкритті таємниці імені має і решта літер. Завдяки цьому ми можемо довідатися про окремі риси характеру людини, яка носить певне ім'я. Якщо літери в імені повторюються, то певна риса характеру виражена більш чітко. Сформулюємо лінгвопсихологічну характеристику Джеймса і його друзів, Клайда та Фреда: Д - бажання бути першим, чинити нестандартно, іноді непродумано; $Ж-$ прагнення до естетичної завершеності, чарівність; $E$ - щирість і владолюбство; Й - недовірливість, страх за добробут свого тіла; $M$ - прагнення скрізь побувати і все випробувати на власному досвіді; $C$ - блиск і харизматичність; $K$ загадковість і наявність певної таємниці; Л - тяга до тілесного комфорту; $A-$ працелюбність; $\Phi$ - твердість духу; $P$ - вірність даному слову.

Звичайно, такий аналіз рис характеру людей за наявними в їхньому імені літерами не досконалий. Однак, варто зазначити, що переважно вони збігаються. Наприклад, характер Фреда цілком відповідає поясненню літер його імені. Що ж стосується літер в іменах Джеймса та Клайда, то тут є окремі розбіжності, хоча в цілому характери героїв твору відповідають характеристиці, виведена на основі складників антропонімів.

Не менш важливим аспектом нашого дослідження стали граматичні функції власних назв, зокрема імен головних героїв. Антропопоетоніми 
Джееймс, Клайд, Фред переважно вживаються у ролі підмета (суб'єкта висловлювання): Фред сів $і$ лінькувато потягнувся. Не менш продуктивні функції прямого і непрямого додатка (об’єкта висловлювання): Клайд мляво підвівся $і$ підійшов до Дюжеймса та неузгодженого означення (атрибутивної синтаксеми): Очі Клайда зацікавлено блиснули. В. Владко у своїй повісті також активно використовує різновид означення - непоширену прикладку: Дюжеймс-Коротун з самого початку боявся изього.

Досить різноплановими були спроби назвати знайдену космічну речовину. Варіантів назв було декілька, хоча остаточно на жодному з них герої твору не зупинилися. Були запропоновані такі номінації: космічна плісень Джеймса Марчі і Клайда Тальбота, Космоцилін, Астроміцин, Астроміuин СТ, Астроміцин СТМ, Астроміциин СТМБ. Стосовно усіх назв можна сказати, що жодна 3 них не відповідала побаченим властивостям метеоритної цвілі; крім того, лише назва Космоцилін не зареєстрована у сучасній лексиці. Великі літери дуже просто пояснити, вони вказують на прізвища винахідників.

Розглядаючи інші власні назви фантастичної повісті В. Владка «Фіолетова загибель», варто зауважити, що, наприклад, хоропоетоніми, які зустрічаються в творі, є реальними назвами (штат Айдахо, Америка, Чікаго, Франція, Куба, Сіетл, Каліфорнія тощо).

Практично неможливо достовірно визначити реальність існування запропонованих автором фірм, оскільки їх кількість у сучасному світі величезна i, до того ж, деякі найменування транслітеровані кирилицею (Оффіс-Сейнтер, Байолоджікал Лімітед, Індастрі ов кемікал продактс, Дженерал Дайнемікс), значно відрізняються від оригіналу і важко піддаються будь-якому поясненню.

Космопоетоніми, навпаки, переважно є реалонімами, окрім можливої назви знайденого головними героями метеорита - Метеорит Джеймса Марчі $i$ Клайда Тальбота та найменування згадуваного у повісті метеорита - Мурейський метеорит. В історії відома лише подібна назва Ново-Урейський метеорит, тому можна припустити, що автор спеціально використав таку номінацію.

У творі зафіксовано лише один гідропоетонім та один едитопоетонім, та вони не стають об'єктом нашої зацікавленості, оскільки є реальними назвами (річка Снайк, Скелясті гори).

Гемеропоетонім, який використав автор, $\epsilon$ транслітерацією англійського варіанту назви Попюлар сайєнс, що в перекладі означає «науково-популярний» (журнал). Для українських видань (та й для зарубіжних) такий варіант оніма є неприйнятним.

Отже, усі власні назви, зафіксовані у фантастичній повісті В. Владка «Фіолетова загибель», утворюють цілісну і зрозумілу онімну картину. Кожен поетонім влучно підібраний автором і підкреслює характерні риси денотатів. При дослідженні поетонімікону фантастичної повісті 
«Фіолетова загибель» стало очевидним, що й надалі слід працювати над вивченням ономастиконів творів цього жанру, створених як В. Владком, так і іншими українськими письменниками-фантастами.

\section{Література}

1. Владко В. М. Сивий Капітан: Роман; Фіолетова загибель : Повість. / В. М. Владко. - К. : Дніпро, 1967. $-512 \mathrm{c}$.

2. Ісат Ю. А. 2500. Чоловічі та жіночі імена : Походження, значення, вибір / Ю. А. Ісат. - Донецьк : ТОВ ВКФ «БАО», 2005. $-560 \mathrm{c}$.

3. Тайна имени / М. П. Загурская. - Х. : Фолио, 2008. -314 c.

4. http://taina-imeni.com. 